GEOLOGICA BALCANICA, 49 (1), Sofia, April 2020, pp. 67-72.

\title{
Palaeoenvironments of northwestern Bulgaria and northeastern Serbia during the Jurassic
}

\author{
Platon Tchoumatchenco
}

Geological Institute, Bulgarian Academy of Sciences, Acad. G. Bonchev Str., Bl. 24, 1113 Sofia, Bulgaria

(Published based on unfinished manuscript of the author: April, 2020)

\begin{abstract}
Jurassic rocks in the Danube Region of northwestern Bulgaria and northeastern Serbia have been the subject of numerous earlier studies that have shown notable similarities between their sedimentary facies and depositional environments. In terms of regional palaeotectonic zonation, this area represents the westernmost parts of the Vidin Early-Middle Jurassic Complex Horst and the Mihaylovgrad Early-Middle Jurassic Graben in NW Bulgaria, as well as the easternmost part of the Lower Danubicum in NE Serbia, which collectively take part of the Jurassic Moesian Platform. For compiling an overall conception of the palaeoenvironments that existed during the Jurassic, nine palaeoenvironmental sketch maps, from the Aalenian to the late Tithonian, have been composed in this study, based on reinterpretation of the data borrowed from previous literature. It became evident that the Middle Jurassic sedimentary successions of the Danube Region record an evolution from an initially isolated lacustrine-palustrine depositional setting (Aalenian) to rapidly expanding shallow to moderately deeper-marine sandy-calcareous setting (late Bajocian-early Callovian). From the middle Callovian and onwards, during the Late Jurassic, the region became an area of laterally extensive pelagic and platform carbonate deposition. This interpretation is consistent with the available earlier data, but it links the facies and their respective settings from NW Bulgaria to NE Serbia, which has not been made to date and will be of benefit for future regional correlations.
\end{abstract}

Tchoumatchenco, P. 2020. Palaeoenvironments of northwestern Bulgaria and northeastern Serbia during the Jurassic. Geologica Balcanica 49 (1), 67-72.

Keywords: Jurassic palaeoenvironments, NW Bulgaria, NE Serbia.

\section{PREFACE}

In the last years of his life, Platon Tchoumatchenco focused his work on the history of the geological science. In this respect, he was able to publish a huge amount of valuable information due to his patience and attention to detail, which have always been evident in his research studies. Despite being engrossed in other matter, which is different from the interests of his earlier years, Platon Tchoumatchenco never forgot his favourite field of study, palaeoecology. I was surprised when, a few years ago, he invited me to collaborate in the preparation of an abstract on the Jurassic palaeoenvironments of the Danube Region of northwestern Bulgaria and northeastern Serbia. The abstract was a poster presentation at the International Scientific Conference "Geoparks and Modern Society”, which took place in the early autumn of 2018 in the town of Belogradchik (see Sapunov et al., 2018). In this poster, Tchoumatchenco summarized his knowledge on the Jurassic geology of the Danube Region, which he had accumulated during the long years of work in the Vidin area, but also achieved as a result of his intense contacts and collaboration with colleagues from Serbia. Nine palaeoenvironmental maps were included in the poster, and the maps represented Tchoumatchenco's ideas on the evolution of the marine environments of this area, from the Aalenian (Middle Jurassic) to the late Tithonian (Late Jurassic). However, these maps remained only on the large sheet of the poster. Platon Tchoumatchenco considered publishing them, but his sudden death in 2019 thwarted his intentions. Proceeding from the fact that the palaeoenvironmental maps were completed and also that Tchoumatchenco had started work on a preliminary manuscript, the main results of his work are presented in this paper to the attention of the geologists from both Bulgaria and Serbia. Platon Tchoumatchenco was an extraordinary palaeontologist with original conceptions, and a man who has always been devoted to science. With the publication of his latest views, I would like to express my deep respect for his great contributions to the Jurassic geology of Bulgaria and to pay tribute to his memory. 


\section{INTRODUCTION}

The Jurassic strata and the Jurassic development of the area of northwestern Bulgaria have been the subject of extensive studies in many publications (e.g., Bončev and Popov, 1935; Stephanov, 1961, 1966, 1972; Stephanov and Tzankov, 1970; Tchoumatchenco, 1977, 1978a-d; Sapunov et al., 1988). However, the evidence contained in these papers has long been confined to the Bulgarian/ Serbian state border, and what is beyond the border, in northeastern Serbia, has been known mainly from the publications of Serbian geologists (e.g., Andjelković and Petković, 1975; Andjelković et al. 1996; Radulović et al., 1997). During the previous decade, successful correlations between the

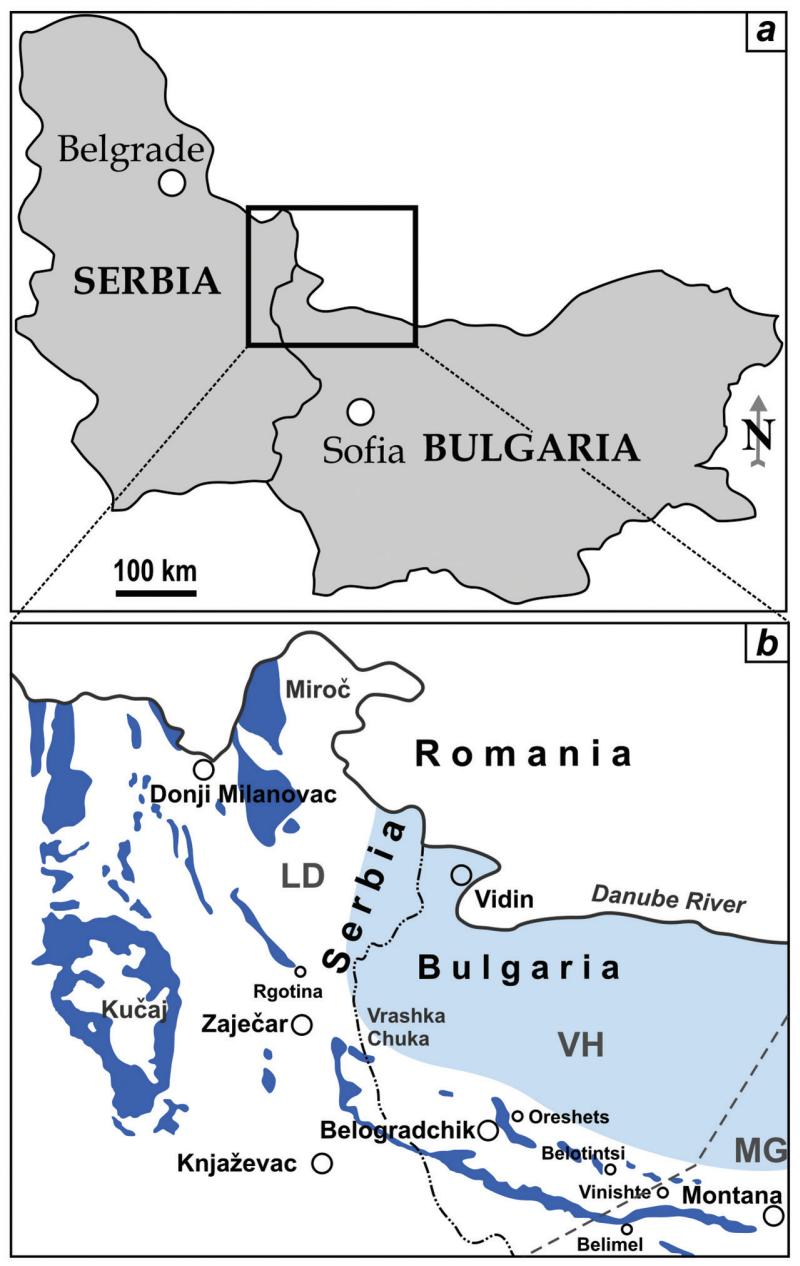

Fig. 1. a) Location sketch map of the area of this study; $b$ ) Outcrops (blue) and subcrops (light blue) of the Jurassic rocks in the Danube River region of NW Bulgaria and NE Serbia (modified from Tchoumatchenco et al., 2011). Abbreviations: LD Lower Danubicum; VH - Vidin Horst; MG - Mihaylovgrad Graben.
Jurassic lithostratigraphic units in NW Bulgaria and NE Serbia were made (Tchoumatchenco et al., 2006a, 2006b, 2008, 2010a, 2010b, 2011). A result of this is that correlations between the Bulgarian and Serbian Jurassic lithostratigraphic successions have now attained the highest levels of reliability and detail. The present work is an attempt to continue the latest correlation efforts by extending the available Jurassic palaeoenvironmental sketch maps for NW Bulgaria (Sapunov et al., 1988) up to the Danube Region in NE Serbia. The maps put forward in this study reflect the Jurassic depositional environments, based on the data borrowed from previous literature for the Jurassic strata cropping out in two areas: Montana-Belogradchik-Vidin (NW Bulgaria) and Knjaževac-Kučaj-MiročDonji Milanovac (NE Serbia) (Fig. 1). These areas have shown that they have common features regarding the Jurassic successions. However, there are also local specifics that prevent the correlation. The latter were not taken into account herein and will need to be considered carefully elsewhere. Nevertheless, there are sufficient features in the sedimentary record that allowed a clear picture of the depositional environments of the two regions to be drawn.

\section{JURASSIC PALAEOENVIRONMENTS}

During the Early-Middle Jurassic, the area of northwestern Bulgaria took part of the Vidin Early-Middle Jurassic Complex Horst (Sapunov et al., 1988). The latter palaeotectonic unit is a southern extension of the Lower Danubicum from NE Serbia (see Kräutner and Krstić, 2003), and these equivalent units were developed after the Old Cimmerian Orogeny on the territory of present-day NW Bulgaria and NE Serbia. The Vidin Jurassic Horst was limited from the west by the Izdremets Jurassic Graben (the southern prolongation of the Infra-Getic in East Serbia sensu Tchoumatchenco et al., 2011), and from the SSE by the Mihaylovgrad Early-Middle Jurassic Graben, respectively (Sapunov et al., 1988). The Vidin Horst and the Mihaylovgrad Graben, as well as the Lower Danubicum, took part of the Jurassic Moesian Platform, on which various depositional environments were developed. However, in the Mihaylovgrad Graben, the marine sedimentation started at the late Hettangian, whereas the Vidin Horst represented a dryland, composed of diverse Paleozoic and Triassic rocks, in conditions of erosion and denudation. The latter environments persisted throughout the Early Jurassic, both in NW Bulgaria and NE Serbia. 


\section{Middle Jurassic palaeoenvironments}

In latest Toarcian-earliest Aalenian times, a lacustrine to palustrine deposition started in separate locations to the northwest and southeast of the present-day town of Belogradchik and in the Miroč Mt (Fig. 2a). Heterogranular oligomict sandstones, conglomerates, clays and coal-bearing shales, sporadically containing Cycadophyta and referred to the Vrashka Chuka Formation, were deposited (Sapunov et al., 1988). The first marine shallow sublittoral environments, with sandy-pebbly bottom and agitated water, were imposed, into a narrow strip with NW-SE trend, on the southern and central part of the Vidin Horst, in which the oligomict sandstones and conglomerates of the Kichera Formation and the Staro Selo Clastites were accumulated (Tchoumatchenco et al., 2011). Poor fossil assemblages of bivalves and less common brachiopods (often fragmented), as well as poorly preserved single ammonites and belemnites, occur as extreme rarities in the clastic rocks. This style of deposition continued until the end of the Aalenian, but with reduction and liquidation of the continental and gradual expansion of the marine environments (see Fig. 2b). Generally, the shallow sublittoral environments existed on the Vidin Horst up to the end of the late Bajocian (see Tchoumatchenco, 1977; 1978a; Sapunov et al., 1988). However, at the end of the early Bajocian, thin "tongues" of sandy limestones to calcareous sandstones, referred to the Polaten Formation, were formed into narrow areas to the east and the south of Belogradchik Town. Equivalent strata, called Štubic Clastites, were accumulated into separate localities to the south of the town of Donji Milanovac (Tchoumatchenco et al., 2011). These sediments were deposited in shallow to moderately-deep sublittoral environments with calcareous bottom and agitated water. In both NW Bulgaria and NE Serbia, the rocks recording the latter environments have preserved diverse brachiopod faunas (Tchoumatchenco, 1977, 1978d). It seems that, towards the end of the Bajocian, the terrigenous-carbonate sedimentation significantly widened its range (see Fig. 2c).

The extension of the marine terrigenous-carbonate sedimentation on the Vidin Horst continued until the middle Bathonian and was associated with the deepening of the basin, resulting in both an increase in the carbonate component and the formation of deeper-marine depositional environments. During the mid-late Bathonian and the early Callovian, clayey-calcareous muddy sea bottoms were imposed (see Fig. $3 a, b$ ). The latter environments resulted in the accumulation of marl-limestone de-
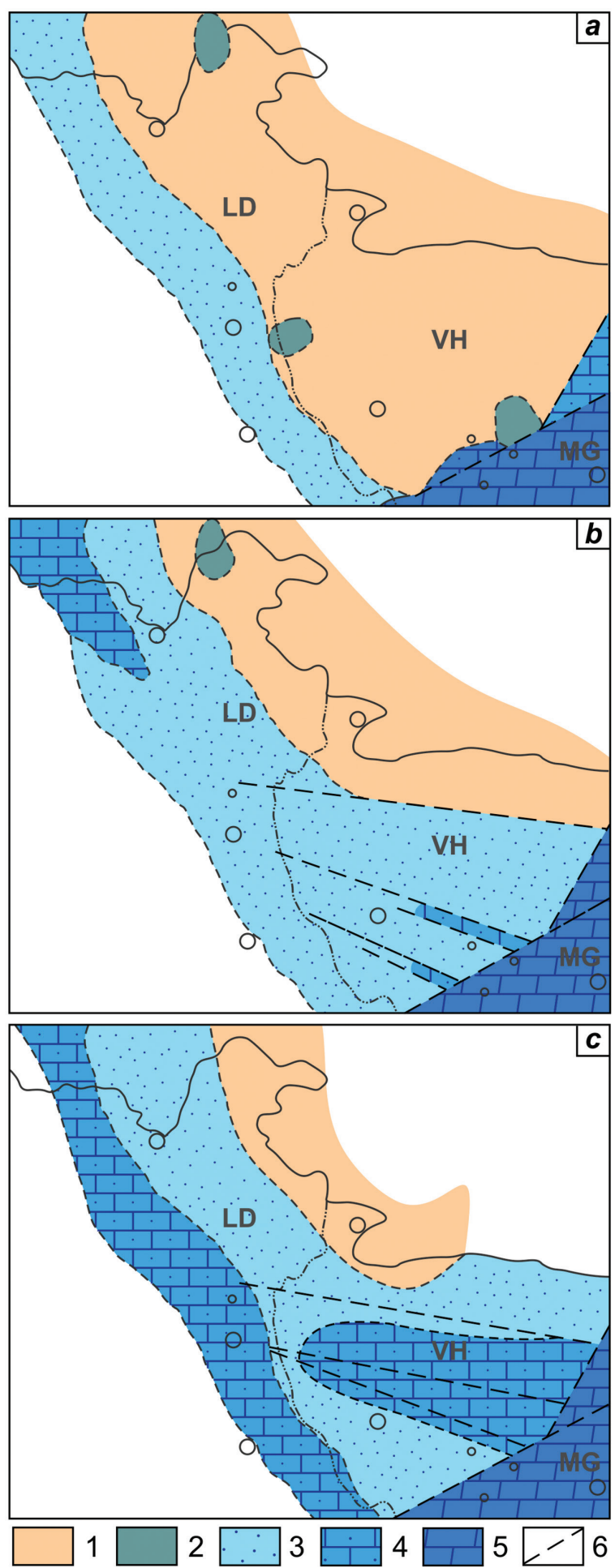

Fig. 2. Palaeoenvironmental sketch maps of NW Bulgaria and NE Serbia: $a$ ) for the beginning of the Aalenian; $b$ ) for the end of the Aalenian; $c$ ) for the late Bajocian. Presumable environments: 1) dryland in conditions of erosion and denudation; 2) continental environments; 3) shallow sublittoral environments with sandy bottom and agitated water; 4) shallow to deep sublittoral environments with calcareous bottom and agitated water; 5) deep sublittoral environments with muddy bottom and slightly agitated water; 6) palaeofaults. Abbreviations: LD Lower Danubicum; VH - Vidin Horst; MG - Mihaylovgrad Graben. 

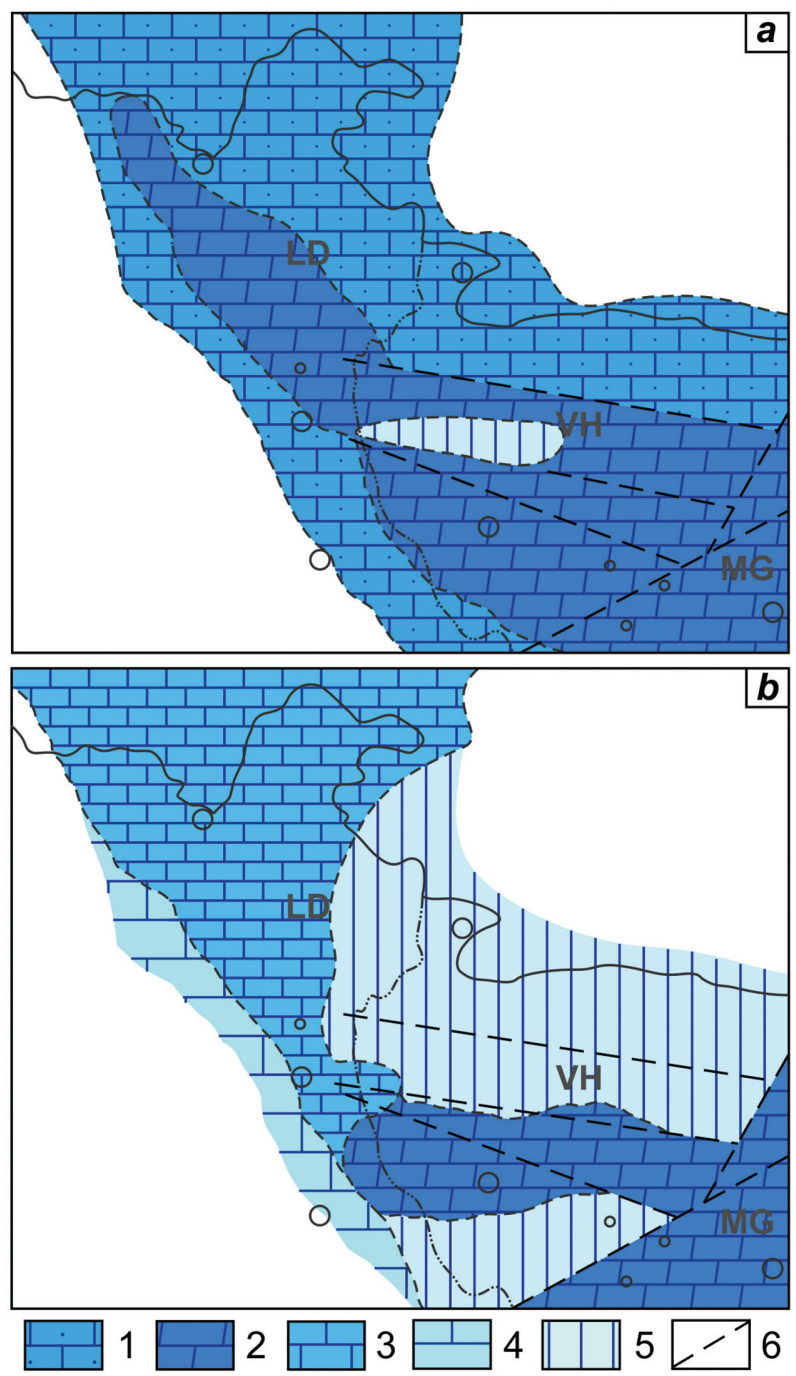

Fig. 3. Palaeoenvironmental sketch maps of NW Bulgaria and NE Serbia: $a$ ) for the middle Bathonian; $b$ ) for the late Bathonian. Presumable environments: 1) shallow to deep sublittoral environments with calcareous bottom and agitated water; 2) deep sublittoral environments with muddy bottom and slightly agitated water; 3) shallow to deep sublittoral environments with calcareous bottom and agitated water; 4) shallow sublittoral environments with calcareous bottom and agitated water; 5) littoral and sublittoral environments with strong bottom currents (areas of non-deposition and submarine washout); 6) palaeofaults. Abbreviations: LD - Lower Danubicum; VH Vidin Horst; MG - Mihaylovgrad Graben.

posits, referred to the Bov Formation in NW Bulgaria (Sapunov et al., 1988), and called "Posidonia" beds in NE Serbia (Tchoumatchenco et al., 2011). At that time, several normal regional faults, with E-W trends, were presumably also present and two areas of reduced sedimentary influx, resulting from non-deposition or submarine washout, were developed. In these areas of littoral and sublittoral
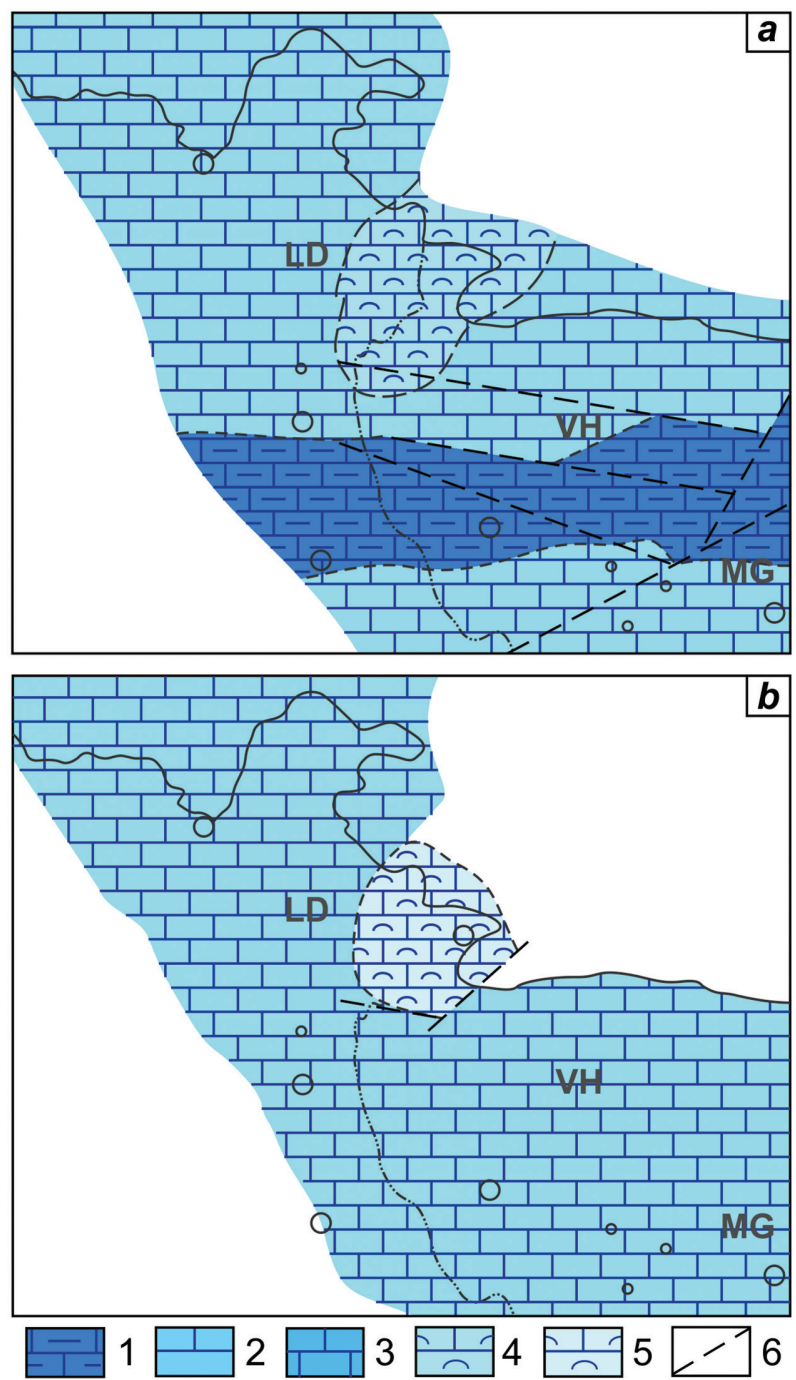

Fig. 4. Palaeoenvironmental sketch maps of NW Bulgaria and NE Serbia: $a$ ) for the early Callovian; $b$ ) for the middle Callovian. Presumable environments: 1) deep sublittoral environments with muddy bottom and slightly agitated water; 2) sublittoral and shallow epibathyal environments with calcareous bottom and slightly agitated water; 3) shallow sublittoral environments with sandy bottom and agitated water; 4) moderately deep sublittoral environments with calcareous bottom and slightly to moderately agitated water; 5) shallow sublittoral environments with calcareous bottom and agitated water; 6) palaeofaults. Abbreviations: LD - Lower Danubicum; VH - Vidin Horst; MG Mihaylovgrad Graben.

environments with strong bottom currents, highly condensed fossil localities have been preserved. For instance, from such fossil sites are the Bathonian ammonites previously studied by Stephanov (1966, 1972), as well as the classical locality to the north of Belogradchik, in which Bončev and Popov (1935) proved for the first time the presence of the Callovian in Bulgaria. Similar depositional environments 
have been recorded in the Bujkovo Sandstones in NE Serbia. In the early Callovian, however, a small sector of NE Serbia became an area of deposition of thick-bedded and ferruginized bioclastic limestones, referred to the Rgotina/Gulenovtsi Beds (Tchoumatchenco et al., 2011). These sediments were accumulated into shallow to moderately-deep sublittoral environments with calcareous bottom and slightly agitated to moderately agitated water.

From the middle Callovian to the end of the Jurassic, the area of both NW Bulgaria and NE Serbia became a field of extensive carbonate deposition. Initially, micritic and partly intraclastic-bioclastic limestones, i.e., the Yavorets Formation and the Vidlič Limestones (pars.), were deposited in deep sublittoral to shallow epibathyal environments with calcareous bottom and slightly agitated water (Fig. $4 a$ ). Bioclastic, bioconstructed and micritic limestones (locally with secondary dolostones), referred to the Slivnitsa Formation in NW Bulgaria and to the Basara Limestones in NE Serbia, were also deposited in a shallow sublittoral environment with calcareous bottom and agitated water (Fig. $4 b$ ).

\section{Late Jurassic palaeoenvironments}

From the late Oxfordian to the early Tithonian, in both NW Bulgaria and NE Serbia, carbonate deposition in deep sublittoral to shallow epibathyal environments, with calcareous bottom and slightly agitated water, continued to exist (see Fig. $5 a, b$ ). Near the town of Vidin and in the Donji Milanovac-Miroč area, bioclastic, bioconstructed and micritic limestones continued to accumulate in shallow sublittoral environments. In the area of the town of Belogradchik, however, in a deep sublittoral to moderately deep epibathyal environments with calcareous bottom and slightly agitated water, nodular limestones of the pelagic facies "Ammonitico rosso" were deposited. During the middle and the late Tithonian, micritic and partly lithoclastic limestones (Glozhene Formation, type Majolica) were deposited in deep sublittoral to shallow epibathyal environments with calcareous bottom and slightly agitated water. In NE Serbia, reefal limestones, as well as thick-bedded micritic limestones, were deposited in shallow sublittoral environments with calcareous bottom and agitated water. These sediments were referred to the Crni Vrh Limestones, which are analogous to the Slivnitsa Formation in Bulgaria (Tchoumatchenco et al., 2011). In the vicinity of Donji Milanovac Town, nodular limestones of "Ammonitico rosso" facies were accumulated between the Majolica-type sediments and the reefal limestones.
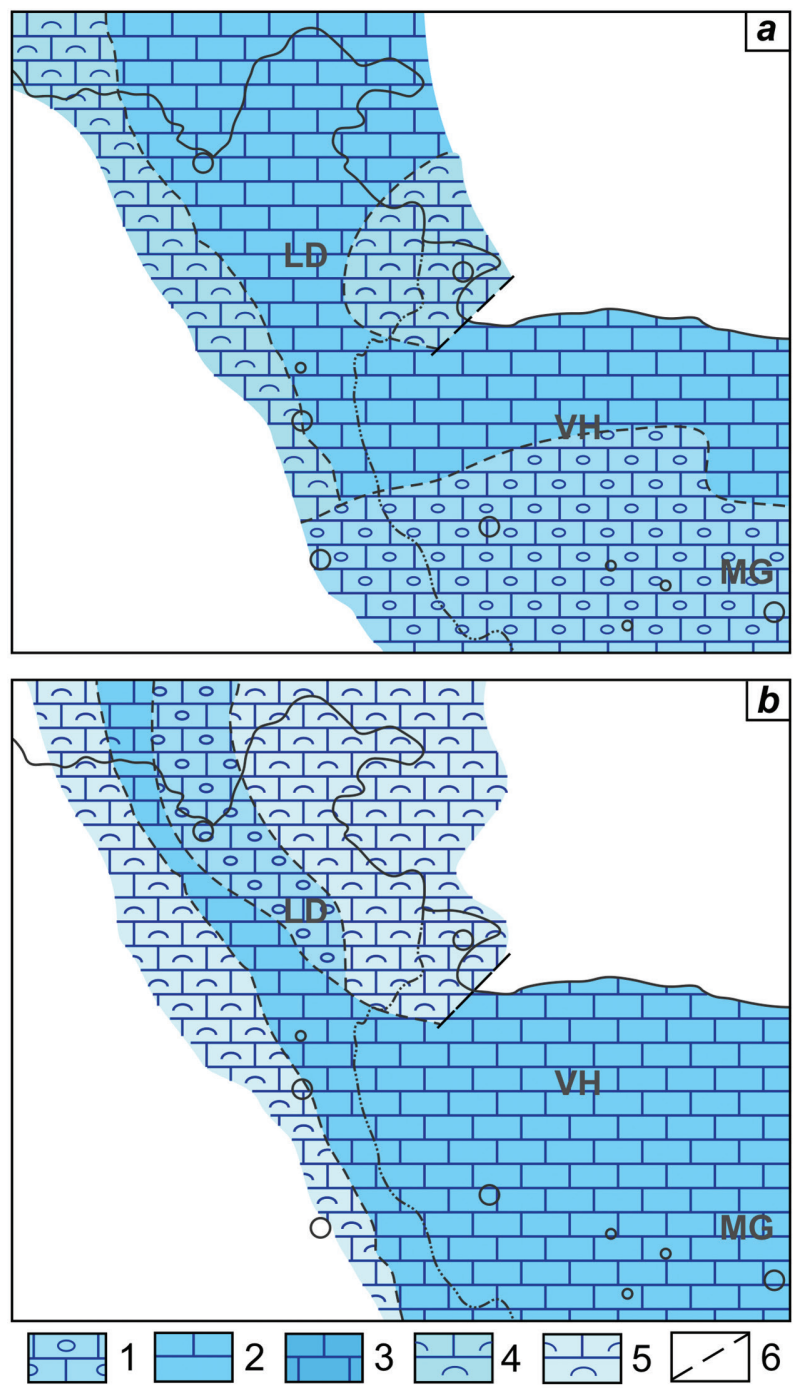

Fig. 5. Palaeoenvironmental sketch maps of NW Bulgaria and NE Serbia: $a$ ) for the late Oxfordian-early Tithonian; $b$ ) for the late Tithonian. Presumable environments: 1) deep sublittoral to moderately deep epibathyal environments with calcareous bottom and slightly agitated water; 2) sublittoral and shallow epibathyal environments with calcareous bottom and slightly agitated water; 3) shallow sublittoral environments with sandy bottom and agitated water; 4) moderately deep sublittoral environments with calcareous bottom and slightly to moderately agitated water; 5) shallow sublittoral environments with calcareous bottom and agitated water; 6) palaeofaults. Abbreviations: LD - Lower Danubicum; VH - Vidin Horst; MG - Mihaylovgrad Graben.

\section{CONCLUSION}

The Middle Jurassic sedimentary successions of the Danube Region in NW Bulgaria and NE Serbia record an evolution from an initially isolated lacustrine-palustrine depositional setting (Aalenian) to rapidly expanding shallow to moderately deeper-marine sandy and carbonate setting (late Bajocian-early 
Callovian). This style of deposition supports the idea of a delayed Jurassic marine transgression in both NW Bulgaria and NE Serbia, which is a conspicuous feature that has rarely been taken into account before. From the middle Callovian and onwards, during the Late Jurassic, the region under consideration herein became an area of laterally extensive and thick pelagic and platform carbonate deposition. Therefore, a clear transition from a depositional stage, with differential subsidence rates and formation of horst-and- graben structures and a wide variability of sedimentary facies (Middle Jurassic), to a depositional stage, with a stable carbonate regime and relatively uniform topography (Late Jurassic) can be assumed.

\section{Acknowledgements}

Warm thanks are expressed to Acad. Prof. Todor Nikolov for much-appreciated reading of the manuscript.

\section{REFERENCES}

Andjelković, M., Petković, K. (Eds). 1975. Géologie de la Serbie, II-2 Stratigraphie, Mésozoïque. Institut de Géologie Régionale et de Paléontologie, Faculté des Mines et de Géologie, Université de Belgrade, 368 pp. (in Serbian).

Andjelković, M., Mitrović-Petrović, J., Jankičević, J., Rabrenović, D., Andjelković, J., Radulović, V. 1996. Geology of Stara Planina - stratigraphy. Institut de Géologie Régionale et de Paléontologie, Faculté des Mines et de Géologie, Université de Belgrade, 247 pp. (in Serbian, with English summary).

Bončev, E., Popov, G. 1935. Über die Fauna der Macrocephalites-Schichten im Venec-Planina bei Belogradčik (N.W. Bulgarien). Geologica Balcanica 1 (3), 117-126 (in Bulgarian, with German summary).

Kräutner, H.G., Krstić, B. 2003. Geological map of the Carpatho-Balkanides between Mehadia, Oraviţa, Niš and Sofia 1:300 000. Geoinstitute, Belgrade.

Radulović, V., Bošković, D., Rabrenović, D. 1997. On the Dogger (Aalenian) age of the Vrška Čuka coal overbed, Eastern Serbia. Annales Géologiques de la Péninsule Balkanique 61 (2), 139-151.

Sapunov I., Tchoumatchenco, P., Mitov, P. 1988. The Jurassic development of Northwest Bulgaria. Geologica Balcanica 18 (1), 3-82.

Sapunov, I., Tchoumatchenco, P., Metodiev, L. 2018. The "Belogradchik Geopark" (NW Bulgaria) during the Jurassic. International Scientific Conference "Geoparks and Modern Society", Abstracts, 52.

Stephanov, J. 1961. The Bathonian in the section of the Belogradchik-gara Oreshets road (North-west Bulgaria). Bulletin of the Geological Institute 9, 337-355 (in Bulgarian, with Russian and English summaries).

Stephanov, J. 1966. The Middle Jurassic ammonite genus Oecotraustes Waagen. Travaux sur la géologie de Bulgarie, Série Paléontologie 8, 29-69.

Stephanov, J. 1972. Monograph on the Bathonian ammonite genus Siemiradzkia Hyatt, 1900 (nomenclature, taxonomy and phylogeny). Bulletin of the Geological Institute, Series Palaeontology 21, 5-82.

Stephanov, J., Tzankov, Tz. 1970. On the lithostratigraphy of the Lower and Middle Jurassic marine rocks in the Belogradchik area. Bulletin of the Geological Institute, Series Stratigraphy and lithology 19, 41-59 (in Bulgarian, with Russian and English summaries).

Tchoumatchenco, P. 1977. Sur la stratigraphie des brachiopodes du Jurassique moyen dans la région de Belogradchik. Review of the Bulgarian Geological Society 38 (3), 314319 (in Bulgarian, with French abstract).
Tchoumatchenco, P. 1978a. Sur les paléocourants dans le bassin du Jurassique moyen de la région de Belogradčik. Review of the Bulgarian Geological Society 39 (1), 17-29 (in Bulgarian, with French summary).

Tchoumatchenco, P. 1978b. Sur certains problèmes de la lithostratigraphie du Jurassique moyen en Bulgarie du nord-ouest. Annuaire de l'Université de Sofia, Faculté de géologie 69 (1), 171-192 (in Bulgarian, with French summary).

Tchoumatchenco, P. 1978c. Callovian-Tithonian Brachiopoda from the northern limb of the Belogradčik Anticlinorium, Northwest Bulgaria. Palaeontology, Stratigraphy and Lithology 8, 3-54 (in Bulgarian, with Russian and English abstracts).

Tchoumatchenco, P. 1978d. Brachiopodes du Jurassique moyen des environs du village de Dolni Lom, District de Vidin (Bulgarie du Nord-ouest). Annuaire de l'Université de Sofia 69 (1), 193-232 (in Bulgarian, with French abstract).

Tchoumatchenco, P., Rabrenović, D., Radulović, B., Radulović, V. 2006a. Transborder (south-east Serbia/west Bulgaria) correlations of the Jurassic sediments: main Jurassic paleogeographic units. Annales Géologiques de la Péninsule Balkanique 67, 13-17.

Tchoumatchenco, P., Rabrenović, D., Radulović, B., Radulović, V. 2006b. Transborder (south-east Serbia/west Bulgaria) correlations of the Jurassic sediments: InfraGetic Unit. Annales Géologiques de la Péninsule Balkanique 67, 19-33.

Tchoumatchenco, P., Rabrenović, D., Radulović, B., Malešević, N., Radulović, V. 2008. Transborder (south-east Serbia/ west Bulgaria) correlations of the Jurassic sediments: Getic and Supra-Getic units. Annales Géologiques de la Péninsule Balkanique 69, 1-12.

Tchoumatchenco, P., Rabrenović, D., Radulović, V., Malešević, N. 2010a. Transborder (East Serbia/West Bulgaria) EarlyMiddle Jurassic (Hettangian-Early Callovian) palaeogeographical correlations. Comptes rendus de l'Académie bulgare des Sciences 63 (10), 1505-1514.

Tchoumatchenco, P., Rabrenović, D., Radulović, V., Malešević, N. 2010b. Transborder (East Serbia/West Bulgaria) Middle-Late Jurassic (Middle Callovian-Tithonian) palaeogeographical correlations. An easy. Comptes rendus de l'Académie bulgare des Sciences 63 (11), 1619-1629.

Tchoumatchenco, P., Rabrenović, D., Radulović, B., Malešević, N., Radulović, V. 2011. Transborder (north-east Serbia/ north-west Bulgaria) correlations of the Jurassic lithostratigraphic units. Annales Géologiques de la Péninsule Balkanique $72,1-20$. 